\title{
Effects of phytate and minerals on the bioavailability of oxalate from food
}

Article

Accepted Version

Israr, B., Frazier, R. A. and Gordon, M. H. (2013) Effects of phytate and minerals on the bioavailability of oxalate from food. Food Chemistry, 141 (3). pp. 1690-1693. ISSN 03088146 doi: https://doi.org/10.1016/j.foodchem.2013.04.130 Available at https://centaur.reading.ac.uk/32877/

It is advisable to refer to the publisher's version if you intend to cite from the work. See Guidance on citing.

Published version at: http://dx.doi.org/10.1016/j.foodchem.2013.04.130

To link to this article DOI: http://dx.doi.org/10.1016/j.foodchem.2013.04.130

Publisher: Elsevier

All outputs in CentAUR are protected by Intellectual Property Rights law, including copyright law. Copyright and IPR is retained by the creators or other copyright holders. Terms and conditions for use of this material are defined in the End User Agreement.

\section{www.reading.ac.uk/centaur}

\section{CentAUR}

Central Archive at the University of Reading

Reading's research outputs online 


\section{Effects of phytate and minerals on the bioavailability of oxalate from food}

2

3

4

5

6

7

8

9

10

11

12

13

14

15

16

17

18

19

\author{
Beenish Israr $^{*}$, Richard A. Frazier ${ }^{1}$, Michael H.Gordon ${ }^{1}$
}

${ }^{1}$ Department of Food and Nutritional Sciences, University of Reading, Whiteknights, PO Box 226, Reading RG6 6AP, UK

\section{Abstract:}

Phytate and mineral cations are both considered as important dietary factors for inhibiting the crystallisation of calcium oxalate kidney stones in susceptible individuals. In this paper, the phytate and mineral composition of whole bran cereals (wheat, barley and oat) and legumes were

determined together with their soluble and insoluble oxalate concentrations in order to investigate the effects on oxalate solubility. The oat bran sample had the highest soluble oxalate concentration at $79 \pm 1.3 \mathrm{mg} / 100 \mathrm{~g}$, while total and soluble oxalate concentrations in the food samples studied range from 33-199 mg/100 g and 14-79 mg/100 g, respectively. The phytate concentration was in the range from $227-4393 \mathrm{mg} / 100 \mathrm{~g}$ and the concentrations of cations were in the range $54-70 \mathrm{mg} / 100 \mathrm{~g}$ for calcium, $75-398 \mathrm{mg} / 100 \mathrm{~g}$ for magnesium, $244-1529 \mathrm{mg} / 100 \mathrm{~g}$ for potassium and 4-11 mg/100g for iron. Soluble oxalate concentration did not increase in proportion to total oxalate, and the phytate concentration in all foods was sufficient to contribute to an increase in soluble oxalate concentration by binding calcium.

Key words: Bioavailability, calcium, minerals, oxalate and phytate

\footnotetext{
*Corresponding author.Tel:+44 (0) 7550492211 ; Fax: +44 (0) 1183787708

E-mail address: beenish_israr@hotmail.com b.israr@pgr.reading.ac.uk (B.israr).
} 


\section{Introduction}

21 The availability of soluble oxalate from food has been considered to be one of the main

22 contributors to the development of hyperoxaluria, which is the excessive urinary excretion of oxalate (Holmes, Goodman, Assimos, \& Winston-Salem, 1996). Hyperoxaluria can lead to deposition of calcium oxalate (oxalosis) in kidney tissue or crystallisation as calcium oxalate kidney stones (nephrolithiasis) in the urinary tract (Sanz \& Reig, 1992). Foods with oxalate levels greater than $50 \mathrm{mg} / 100 \mathrm{~g}$ are categorized as high oxalate foods, and these include whole bran cereals and legumes (Boontaganon, Jéhanno, \& Savage, 2009; Chai \& Liebman, 2005). Oxalate absorption usually depends on the presence of free or soluble oxalate in the intestine (Brinkley, MgGuire, Gregory, \& Pak, 1981). It has been reported that soluble oxalate is totally released from bran at gastrointestinal $\mathrm{pH}$, but it can combine with calcium already available in the bran sample to form the insoluble salt (Siener, Heynck, \& Hesse, 2001). It is therefore important when assessing intake of oxalate to consider the balance of soluble to insoluble forms of oxalate available from foods.

A main factor that regulates soluble oxalate is the concentration of divalent cation minerals, including calcium and magnesium (Reddy, Sathe, \& Salunkhe, 1982). The presence of cations in the gut has been found to interfere with oxalate absorption. Higher concentrations of cations like calcium and, to a lesser extent, magnesium have been found to decrease oxalate absorption, and their concentration in simultaneously ingested foods has therefore been considered as important with respect to kidney stone formation (Asplin, 2002). The solubility of calcium oxalate is strongly $\mathrm{pH}$ dependent with solubility increasing strongly below $\mathrm{pH} 4$ (Jaeger \& Robertson, 2004). Magnesium oxalate is more soluble than calcium oxalate, $0.07 \mathrm{~g} / 100 \mathrm{ml}$ versus 0.0007 $\mathrm{g} / 100 \mathrm{ml}$ respectively, but it still contributes to insoluble oxalate in the gut, when its 
43 concentration exceeds the solubility limit (Tiselius, 1991). The solubility product constant for 44 magnesium oxalate at $\mathrm{pH} 7$ has been reported as $8.5 \times 10^{-5} \mathrm{~mol}^{2}$. $\mathrm{dm}^{-6}$, compared to $2.7 \times 10^{-9} \mathrm{~mol}^{2}$. $45 \mathrm{dm}^{-6}$ for calcium oxalate (University of Rhode Island, 2001), although the solubility in urine is 46 more complex, since calcium oxalate crystals can occur as mixtures differing in the degree of 47 hydration (Streit, Tran-Ho, \& Königsberger, 1998). It has been suggested that magnesium may 48 have a small effect on oxalate uptake by complexing oxalate and making it less available for absorption (Jaeger \& Robertson, 2004). However, magnesium supplementation also has been

50 reported to have no effect on urinary oxalate level (Allie \& Rodgers, 2003). Phytate is also 51 considered as beneficial with respect to nephrolithiasis due to its antioxidant properties (Graf \&

52 Eaton, 1990), although more recently phytate was found to increase soluble oxalate available for 53 absorption as well as recurrence of kidney stones as a consequence of its combination with 54 calcium in the human gut (Al-Wahsh, 2005). Cereals and legumes have been found to contain 55 high concentrations of phytate (Reddy et al., 1982), which makes it an important factor to 56 consider when evaluating these foods for oxalate.

57 The molar ratio of oxalate to concurrent minerals has been used as a measure of the availability 58 of oxalate for absorption. Molar ratios of oxalate to minerals greater than 2 and phytate to 59 minerals greater than 0.24 have been reported as hazardous (Fassett, 1973; Reddy \& Sathe, 60 2002). This study aimed to investigate the molar ratio of oxalate and phytate to concurrent 61 minerals in common plant materials in order to assess the availability of oxalate for absorption. 62 Few studies on the effect of a combination of oxalate and phytate on the availability of oxalate 63 and its influence on kidney stones have been reported. Although bran and beans are common 64 dietary components, the concentrations of phytate and oxalate in the same samples of these foods 65 have not been reported. The aim of this study was to investigate the effects of oxalate, phytate 
and mineral concentrations on oxalate solubility in order to predict its bioavailability. These

67 findings would allow conclusions to be drawn about the influence of these foods on the risk of

68 hyperoxaluria in susceptible subjects.

\section{Materials and methods}

\subsection{Food samples}

71 Whole bran cereals (wheat bran, barley bran and oat bran) were obtained from Premier Foods,

72 UK. Legumes (red beans and white beans) imported from Spain were purchased at a local

73 market. One batch of each foodstuff was purchased for analysis.

\subsection{Oxalate analysis}

75 Oxalate was extracted by a method based on that described by (Savage, Vanhanen, Mason, \& 76 Ross, 2000).

77 Samples $(1 \mathrm{~g})$ were extracted with $50 \mathrm{ml} 1.0 \mathrm{M} \mathrm{H}_{2} \mathrm{SO}_{4}$ at $21^{\circ} \mathrm{C}$ for $15 \mathrm{~min}$ in a shaking water 78 bath. The extracts were transferred into a $100 \mathrm{ml}$ volumetric flask, and made to volume with 1.0

$79 \mathrm{M} \mathrm{H}_{2} \mathrm{SO}_{4}$ for total oxalate and with distilled water for soluble oxalate. The dissolved oxalate 80 solution was separated by centrifugation at $3000 \mathrm{rpm}$ for $15 \mathrm{~min}$ and passed through a $0.45 \mu \mathrm{m}$

81 nylon syringe filter. The oxalate concentration in each sample was determined by HPLC using an

82 Agilent 1100 series chromatograph with autosampler, isocratic pump and UV/VIS detector set at

$83210 \mathrm{~nm}$. Data capture and analysis were done by using Chemstation software Version A-7.1. A 5

$84 \mu$ injection volume was used with an Aminex Ion exclusion HPX-87H $300 \times 7.8$ mm analytical

85 column fitted with an Aminex Cation-H guard column. Isocratic elution was used with $0.0125 \mathrm{M}$

$86 \mathrm{H}_{2} \mathrm{SO}_{4}$ (Sigma Aldrich, UK) as mobile phase and a flow of $0.5 \mathrm{ml} / \mathrm{min}$. The analytical column

87 was held at $65^{\circ} \mathrm{C}$, and the column was equilibrated with a flow rate of $0.2 \mathrm{ml} / \mathrm{min}$ prior to use. 
89 Phytate was extracted by the method described by (Oberleas \& Harland, 2007). Finely ground dried sample $(1 \mathrm{~g})$ was extracted with $10 \mathrm{ml}$ of $0.66 \mathrm{M} \mathrm{HCl}$ with gentle agitation for $3 \mathrm{~h}$ on a 91 shaking mixer. The sample was centrifuged at $3500 \mathrm{rpm}$ for $10 \mathrm{~min}$, and the supernatant was 92 filtered through a $0.45 \mu \mathrm{m}$ syringe filter into an HPLC vial.

93 The sample was analyzed by HPLC using an Agilent 1050 series chromatograph consisting of 94 two pumps, UV-Vis detector, set at $500 \mathrm{~nm}$ and Chemstation software Version A-8.3. The 95 column was a strong anion-exchange type, Polymer Laboratories PL-Sax $5 \times 0.46 \mathrm{~cm}$, particle 96 size $8 \mu \mathrm{m}$ and $100 \mathrm{~nm}$ pore size (Varian, Inc.Shropshire, UK). A flow rate of $1 \mathrm{ml} / \mathrm{min}$ was used

97 for the mobile phase and $0.5 \mathrm{ml} / \mathrm{min}$ was used for Wade's reagent. The injection volume was 5 $98 \mu \mathrm{l}$. The analytical column was kept at room temperature and equilibrated with $0.01 \mathrm{M}$ methyl 99 piperazine at $\mathrm{pH} 4$ as mobile phase with a flow rate of $0.2 \mathrm{ml} / \mathrm{min}$ before analysis of the sample.

100 The gradient buffer was $0.6 \mathrm{M}$ sodium nitrate in $0.01 \mathrm{M}$ methyl piperazine at $\mathrm{pH}$ 4. Phytate 101 concentration was calculated using $660 \mathrm{~g} \mathrm{~mol}^{-1}$ as the hexaphosphate molecular weight as 102 recommended by (Oberleas \& Harland, 2001).

\section{$103 \quad$ 2.4. Mineral analysis}

104 Calcium, magnesium, potassium and iron were analyzed by atomic absorption 105 spectrophotometry at 422.7, 285.2, 766.5 and $248.3 \mathrm{~nm}$ respectively (Analytik Jena 106 AG,Germany Model NovAA ${ }^{\circledR} 350$ ) (Analysis of agriculture materials, 1986).

107 2.5. Statistical analysis

108 Results are presented as means of triplicate determinations \pm S.E M. Significant differences 109 between samples $(\mathrm{p}<0.05)$ were identified by Analysis of Variance (ANOVA) with the Tukey 110 HSD test. The analysis was carried out with SPSS version 18. 


\section{Results and discussion}

\subsection{Oxalate}

The total oxalate content of wheat bran, oat bran and red beans is shown in Table 1. The oxalate content for intake of $100 \mathrm{~g}$ of test food samples is high compared to the maximum recommended daily intake of oxalate from food which is 40-50 mg/day (American dietetics association, 2005).

The total oxalate content was in the order wheat bran $>$ oat bran $>$ red bean $>>$ barley bran $>$ white bean. However, only soluble oxalate is absorbed, and the soluble oxalate fell in the order oat bran $>$ wheat bran $>$ barley bran $>$ red bean $>$ white bean. Thus, it is clear that the cereal bran samples contained a higher concentration of soluble oxalate than the legume samples. The oxalate content for these foods was within the range reported in the literature (Siener, Hönow, Seidler, Voss, \& Hesse, 2006);,(Chai \& Liebman, 2005); and (Boontaganon et al., 2009) ·

\subsection{Cations}

Oxalate absorption is highly dependent on the availability of the soluble form. Potassium oxalate is an important soluble form for absorption (Brinkley et al., 1981). The proximal small intestine is a major site for absorption of oxalate (Hanes, Weaver, Heaney, \& Wastney, 1999), but changes of $\mathrm{pH}$ throughout the gastrointestinal tract also have an effect on the absorption of oxalate.

Oxalate is more soluble under the acid conditions of the stomach, which ranges from $\mathrm{pH} 1.5-2$, than at higher $\mathrm{pH}$, so insoluble oxalate forms again after passing into the alkaline environment of the small intestine. Thus oxalate which has been solubilised in the stomach will form a sparingly soluble complex again with calcium, magnesium and iron in the intestine. Soluble oxalate is available for absorption from the intestine through the mucosa (Savage \& Catherwood, 2007). 
132 Calcium is the main cation that forms an insoluble complex with oxalate, and thereby reduces

133 absorption from the gut (Benitez, Grijalva, \& Valencia, 1994). Ferrous oxalate is similar in

134 solubility to calcium oxalate, so ferrous ions may contribute to a reduction in soluble oxalate,

135 and iron was identified as a metal that may promote the formation of calcium oxalate stones,

136 whereas magnesium was considered as an inhibitor (Atakan et al., 2007). The range of mineral

137 concentrations in the food samples tested was $23-70 \mathrm{mg} / 100 \mathrm{~g}$ for calcium, $75-398 \mathrm{mg} / 100 \mathrm{~g}$ for

138 magnesium, 244-1382 mg/100 g for potassium and 4-11 mg/100 g for iron (Table 2).

\subsection{Molar ratio of oxalate and minerals}

The presence of cations in foods eaten at the same time as sources of oxalate is highly important

141 for determining the relative concentrations of soluble and insoluble oxalate (Asplin, 2002).

142 Therefore, the potential of foods for contributing to soluble oxalate is best assessed in terms of

143 the oxalate: mineral ratio for minerals that form insoluble oxalate complexes. A ratio greater than

1442 indicates that a food contains excess oxalate that is bioavailable, whereas, foods having a ratio

145 of 1 or less contain enough calcium, or similar minerals, to minimise formation of soluble

146 oxalate (Gontzea \& Sutzescu, 1968). The solubility product constant for calcium oxalate was

147 reported as $2.7 \times 10^{-9} \mathrm{~mol}^{2} . \mathrm{dm}^{-6}$ (URI(Chemistry;University of Rhode Island), 2001). The whole

148 wheat and oat bran samples studied have a molar ratio of oxalate: calcium greater than 2 as

149 shown in Table 3 and the soluble oxalate content is quite high. In contrast, the molar ratio of

150 oxalate: calcium for red kidney beans was 0.91 , and the soluble oxalate content was relatively

151 low compared to the cereal brans. The soluble oxalate content of white beans and barley bran

152 was also low. Magnesium oxalate is more soluble than calcium oxalate with a solubility product

153 constant of $8.5 \times 10^{-5} \mathrm{~mol}^{2} . \mathrm{dm}^{-6}$ (URI(Chemistry;University of Rhode Island), 2001), and it does

154 not form stones at physiological urine concentrations. However, the solubility of the magnesium 
155 salt is sufficiently low to reduce dietary oxalate absorption (Liebman \& Costa, 2000) (Massey, 156 2005). The molar ratio of oxalate: magnesium was low for all foods studied, but magnesium is

157 less effective than calcium in reducing oxalate bioavailability (Brinkley et al., 1981). Potassium

158 oxalate is a soluble form, but the potassium concentration was very low in all the samples 159 analyzed.

\subsection{Phytate}

161 The wheat bran sample contained a high concentration of phytate compared to the other food 162 samples i.e $4393 \pm 1.4 \mathrm{mg} / 100 \mathrm{~g}$. The barley bran sample contained the lowest concentration of 163 phytate, and the phytate concentration in the beans ranged from $610-670 \mathrm{mg} / 100 \mathrm{~g}$. The phytate 164 concentrations were comparable to the values reported in the literature (Kirby \& Nelson, 1988); 165 (Harland, Oke, \& Felix-Phipps, 1988).

\subsection{Molar ratio of phytate and mineral}

167 Phytate has been considered as beneficial for kidney disease due to its ability to chelate metal 168 ions which reduces oxidative reactions (Graf \& Eaton, 1990). However, the ability of phytate to

169 form insoluble complexes with divalent cations in the human gut has the consequence of 170 increasing the availability of soluble oxalate for absorption and urinary excretion (Al-Wahsh, 171 2005). A molar ratio of phytate:calcium $>0.24$ has been found to be associated with reduced 172 calcium bioavailability (Morris \& Ellis, 1985). The solubility product constants for calcium 173 phytate and calcium phosphate were reported as $10^{-22}$ and $2.07 \times 10^{-33} \mathrm{~mol}^{2} . \mathrm{dm}^{-6}$ respectively 174 (Evans \& Pierce, 1981; KTF (Chemical Technology Faculty; University of Split), 2003). A high 175 molar ratio of phytate: Ca was present in the whole bran samples, so this would increase the 
176 soluble oxalate concentration by reducing the availability of minerals for forming insoluble

177 oxalate in the test food samples.

178 The molar ratio of $\mathrm{Mg}$ : phytate was very low in the test samples ranging from 0.15 to 0.41 , and

179 this would further reduce any effect of magnesium on soluble oxalate content.

\subsection{Correlation of molar ratio of oxalate, phytate and minerals}

181 Phytate is known to be effective in chelating minerals. It reduces the availability of complex182 forming minerals in the body and makes oxalate more bioavailable (Brinkley, Gregory, \& Pak, 1990; Harland \& Morris, 1995). Ca binding by fibre is low in wheat and oat brans at gastric pH

184 (Siener et al., 2001), but calcium absorption from the small intestine after intake of wheat bran has been reported to decrease slightly in ileostomy patients, who have had a surgical procedure

to allow them to excrete waste from the small intestine into an external bag, where it is collected

187 (Sandberg, Hasselblad, Hasselblad, \& Hultén, 1982). Phytate complexes with Mg are soluble at

188 low pH (Grynspan \& Cheryan, 1983), but complexes with $\mathrm{Ca}$ and $\mathrm{Fe}$ are less soluble. In soy

189 foods, the content of phytate increased with an increase in oxalate content, so soy foods with a

190 low oxalate content were recommended for kidney stone patients (Al-Wahsh, Horner, Palmer,

191 Reddy, \& Massey, 2005). The wheat bran sample had relatively high insoluble oxalate content

192 despite a high concentration of phytate and a low concentration of calcium. The high magnesium

193 content of the wheat bran sample may contribute to the high insoluble oxalate content. In the oat

194 bran sample, the insoluble oxalate concentration was much reduced compared to the wheat bran

195 which is consistent with the low calcium and magnesium concentrations. The molar ratio of

196 soluble: insoluble oxalate of oat bran was much higher than for the wheat bran as shown in table

197 4. The barley bran sample had a low calcium concentration but a relatively high magnesium 
198 concentration, which is consistent with the values for barley bran reported previously (Dendy \&

199 Bogdan, 2001). The phytate concentration showed a moderate correlation with the insoluble

200 oxalate concentration with an $\mathrm{R}^{2}$ value of 0.46 , but the correlation with the soluble: insoluble

201 oxalate ratio was poor with $\mathrm{R}^{2}<0.01$. The beans had lower soluble: insoluble oxalate ratios than

202 the brans.

203 Conclusion

204 High total oxalate and phytate as well as low calcium and magnesium contents contributed to the 205 high soluble oxalate content in the oat bran sample. The soluble oxalate concentration was higher 206 for the oat bran sample than for the wheat bran sample despite a reverse order for total oxalate, 207 and this can be ascribed to the lower concentration of minerals in the oat bran sample, with the 208 minerals in the wheat bran contributing to a reduction of soluble oxalate in the wheat bran. All 209 the food samples analysed had a phytate: calcium ratio $>0.24$, so this indicates that the phytate 210 concentration is sufficient to reduce the calcium available for binding to oxalate, and thereby 211 contributes to an increase in soluble oxalate Soluble oxalate concentration was relatively low in 212 the barley bran and red kidney bean samples and was not detected in the white bean sample.

\section{Acknowledgement}

214 The author is grateful to the University of Agriculture Faisalabad Faculty Development

215 Programme, Pakistan for providing funds for this study. 


\section{References}

Al-Wahsh, I. A. (2005). Soy oxalate and phytate and risk of kidney stones. PhD dissertation, Washington State University, Washington.

Al-Wahsh, I. A., Horner, H. T., Palmer, R. G., Reddy, M. B., \& Massey, L. K. (2005). Oxalate and phytate of soy foods. Journal of Agricultural and Food Chemistry, 53(14), 5670-5674.

Allie, S., \& Rodgers, A. (2003). Effects of calcium carbonate, magnesium oxide and sodium citrate bicarbonate health supplements on the urinary risk factors for kidney stone formation. Clinical Chemistry and Laboratory Medicine, 41(1), 39-45.

American dietetics association. (2005). Urolithiasis/urinary stones. In ADA Nutrition Care. American dietitics association, (275 mannual). Chicago, USA.

Analysis of agriculture materials. (1986). A manual of the analytical methods used by agriculture development and advisory service. [3rd]. Ministry of Agriculture,Fisheries and Food.

Asplin, J. R. (2002). Hyperoxaluric calcium nephrolithiasis. Endocrinology and Metabolism Clinics of North America, 31(4), 927.

Atakan, I. H., Kaplan, M., Seren, G., Aktoz, T., Gül, H., \& Inci, O. (2007). Serum, urinary and stone zinc, iron, magnesium and copper levels in idiopathic calcium oxalate stone patients. International Urology and Nephrology, 39(2), 351-356.

Benitez, M., Grijalva, M., \& Valencia, M. (1994). Total and soluble iron content and effect of certain inhibitors present in selected varieties of tepary bean (Phaseolus acutifolius). Journal of Agricultural and Food Chemistry, 42(6), 1300-1302.

Boontaganon, P., Jéhanno, E., \& Savage, G. (2009). Total, soluble and insoluble oxalate content of bran and bran products. International Journal of Food, Agriculture and Environment, 7(3-4), 204-206.

Brinkley, L., Gregory, J., \& Pak, C. (1990). A further study of oxalate biovailability in foods. The Journal of Urology, 144(1), 94-96.

Brinkley, L. R. D., MgGuire, J., Gregory, J., \& Pak, C. Y. C. (1981). Bioavailability of oxalate in foods. Urology, 17(6), 534-538.

Chai, W., \& Liebman, M. (2005). Oxalate content of legumes, nuts, and grain-based flours. Journal of Food Composition and Analysis, 18(7), 723-729.

Dendy, D. A. V., \& Bogdan, J. D. (2001). Cereals and cereals products, chemistry and technology. Maryland: Aspen publishers Ine.

Evans, W., \& Pierce, A. (1981). Calcium-phytate complex formation studies. Journal of the American Oil Chemists' Society, 58(9), 850-851.

Fassett, D. W. (1973). Oxalates In:Toxicants occuring naturally in foods (2nd ed.). Washington: National academy of sciences.

Gontzea, I., \& Sutzescu, P. (1968). Natural antinutritive substances in foodstuffs and forages. Basel, New york: S.Karger.

Graf, E., \& Eaton, J. W. (1990). Antioxidant functions of phytic acid. Free Radical Biology and Medicine, 8(1), 61-69.

Grynspan, F., \& Cheryan, M. (1983). Calcium phytate: Effect of pH and molar ratio on in vitro solubility. Journal of the American Oil Chemist's Society, 60(10), 1761-1764.

Hanes, D. A., Weaver, C. M., Heaney, R. P., \& Wastney, M. (1999). Absorption of calcium oxalate does not require dissociation in rats. The Journal of Nutrition, 129(1), 170-173.

Harland, B. F., \& Morris, E. R. (1995). Phytate:A good or bad food component? Nutrition Research, 15, 733-754.

Harland, B. F., Oke, O. L., \& Felix-Phipps, R. (1988). Preliminary studies on the phytate content of Nigerian foods. Journal of Agriculture and Food Chemistry, 41, 125-127. 
Holmes, R. P., Goodman, H. O., Assimos, D. G., \& Winston-Salem, N. C. (1996). Metabolic effects of an oxalate-free formula diet. Urolithiasis, 167.

Jaeger, P., \& Robertson, W. G. (2004). Role of dietary intake and intestinal absorption of oxalate in calcium stone formation. Nephron physiology, 98(2), 64-71.

Kirby, L. K., \& Nelson, T. S. (1988). Total and Phytate phosphorous content of some feed ingredients derived from grains. Nutrition Reports International 137, 227-280.

KTF (Chemical Technology Faculty; University of Split). Solubility Product Constants,2003. www.ktfsplit.hr/periodni/en/abc/kpt.html. Accessed 21.1.13

Liebman, M., \& Costa, G. (2000). Effects of calcium and magnesium on urinary oxalate excretion after oxalate loads. The Journal of Urology, 163(5), 1565-1569.

Massey, L. (2005). Magnesium therapy for nephrolithiasis. Magnesium Research, 18(2), 123-126.

Morris, E. R., \& Ellis, R. (1985). Bioavailability of dietary calcium - effect of phytate on adult men consuming nonvegetarian diets. [Review]. Acs Symposium Series, 275, 63-72.

Oberleas, D., \& Harland, B. (2007). Validation of a column liquid chromatographic method for phytate. Journal of AOAC International, 90(6), 1635-1638.

Oberleas, D., \& Harland, B. F. (2001). Newer methods for phytate analysis. In G. A. Spiller (Ed.), CRC handbook of dietary fiber in human nutrition (3rd ed.). Florida: CRC publisher.

Reddy, N. R., \& Sathe, S. K. (2002). Food phytates: CRC.

Reddy, N. R., Sathe, S. K., \& Salunkhe, D. K. (1982). Phytates in legumes and cereals. Advances in Food Research, 28(1), 92.

Sandberg, A. S., Hasselblad, C., Hasselblad, K., \& Hultén, L. (1982). The effect of wheat bran on the absorption of minerals in the small intestine. British Journal of Nutrition, 48, 185-191.

Sanz, P., \& Reig, R. (1992). Clinical and Pathological Findings in Fatal Plant Oxalosis: A Review. The American Journal of Forensic Medicine and Pathology, 13(4), 342.

Savage, G., \& Catherwood, D. (2007). Determination of oxalates in Japanese taro corms using an in vitro digestion assay. Food Chemistry, 105(1), 383-388.

Savage, G. P., Vanhanen, L., Mason, S. M., \& Ross, A. B. (2000). Effect of Cooking on the Soluble and Insoluble Oxalate Content of Some New Zealand Foods. Journal of Food Composition and Analysis, 13(3), 201-206.

Siener, R., Heynck, H., \& Hesse, A. (2001). Calcium-binding capacities of different brans under simulated gastrointestinal $\mathrm{pH}$ conditions. In vitro study with $45 \mathrm{Ca}$. Journal of Agricultural and Food Chemistry, 49(9), 4397-4401.

Siener, R., Hönow, R., Seidler, A., Voss, S., \& Hesse, A. (2006). Oxalate contents of species of the Polygonaceae, Amaranthaceae and Chenopodiaceae families. Food Chemistry, 98(2), 220-224.

Streit, J., Tran-Ho, L.-C., \& Königsberger, E. (1998). Solubility of the Three Calcium Oxalate Hydrates in Sodium Chloride Solutionsand Urine-Like Liquors. Monatshefte für Chemie/Chemical Monthly, 129(12), 1225-1236.

Tiselius, H. G. (1991). Aspects on estimation of the risk of calcium oxalate crystallization in urine. Urologia Internationalis, 47(4), 255-259.

URI(Chemistry; University of Rhode Island). Solubility product constants near $25^{\circ} \mathrm{C}, 2001$. http://bilbo.chm.uri.edu/CHM112/tables/KspTable.htm. Accessed 21.1.13 
311 Phytate, and total, soluble and insoluble oxalate in food samples (mg/100 $\mathrm{g}$ dry weight \pm 312 SEM).

\begin{tabular}{|l|c|c|c|c|}
\hline Sample & Total oxalate & \multicolumn{1}{l|}{$\begin{array}{l}\text { Soluble } \\
\text { oxalate }\end{array}$} & oxalate & \\
\hline Wheat Bran & $199 \pm 3.5^{\mathrm{c}}$ & $56 \pm 4.2^{\mathrm{c}}$ & $146 \pm 1.8^{\mathrm{d}}$ & $4393 \pm 1.4^{\mathrm{d}}$ \\
\hline Oat Bran & $159 \pm 1.6^{\mathrm{b}}$ & $79 \pm 1.3^{\mathrm{d}}$ & $80 \pm 4.3^{\mathrm{b}}$ & $992 \pm 1.2^{\mathrm{c}}$ \\
\hline Barley Bran & $47 \pm 1.4^{\mathrm{a}}$ & $21 \pm 1.4^{\mathrm{b}}$ & $26 \pm 1.0^{\mathrm{a}}$ & $227 \pm 0.4^{\mathrm{a}}$ \\
\hline Red Kidney Bean & $146 \pm 1.6^{\mathrm{b}}$ & $25 \pm 1.2^{\mathrm{b}}$ & $121 \pm 1.2^{\mathrm{c}}$ & $616 \pm 0.3^{\mathrm{b}}$ \\
\hline White Bean & $33 \pm 2.8^{\mathrm{a}}$ & $\mathrm{nd}$ & $33 \pm 2.0^{\mathrm{a}}$ & $671 \pm 1.3^{\mathrm{bc}}$ \\
\hline
\end{tabular}

313 Results are presented as Mean \pm SEM of triplicate determinations

$314 \mathrm{Nd}=$ not detected; concentration $<0.01 \mathrm{mg} / 100 \mathrm{~g}$

$315{ }^{a-d}$ Numbers with different superscripts in the same column are significantly different $(p<0.05)$ 
317 Calcium, magnesium, potassium and iron from test food samples $(\mathrm{mg} / 100 \mathrm{~g}$ dry weight \pm 318 SEM).

\begin{tabular}{|l|c|c|c|c|}
\hline Sample & Calcium & Magnesium & Potassium & Iron \\
\hline Wheat Bran & $30 \pm 1.6^{\mathrm{b}}$ & $398 \pm 2.5^{\mathrm{b}}$ & $1529 \pm 1.9^{\mathrm{c}}$ & $11 \pm 4.2^{\mathrm{c}}$ \\
\hline Oat Bran & $23 \pm 2.1^{\mathrm{a}}$ & $118 \pm 3.6^{\mathrm{a}}$ & $377 \pm 1.6^{\mathrm{a}}$ & $4 \pm 0.4^{\mathrm{a}}$ \\
\hline Barley Bran & $55 \pm 2.1^{\mathrm{c}}$ & $75 \pm 1.9^{\mathrm{a}}$ & $244 \pm 0.2^{\mathrm{a}}$ & $7 \pm 0.6^{\mathrm{b}}$ \\
\hline Red Bean & $70 \pm 1.7^{\mathrm{d}}$ & $114 \pm 1.5^{\mathrm{a}}$ & $984 \pm 1.5^{\mathrm{b}}$ & $6 \pm 0.2^{\mathrm{ab}}$ \\
\hline White Bean & $54 \pm 0.3^{\mathrm{c}}$ & $166 \pm 2.5^{\mathrm{a}}$ & $914 \pm 3.0^{\mathrm{b}}$ & $8 \pm 0.2^{\mathrm{b}}$ \\
& & & & \\
\hline
\end{tabular}


Table 3

323 Molar ratio of oxalate: minerals and phytate: minerals.

\begin{tabular}{|l|c|c|c|c|c|}
\hline \multicolumn{7}{|c|}{ Test Samples } \\
\hline Parameters & Wheat Bran & Oat Bran & Barley Bran & Red Kidney Bean & White Bean \\
\hline Oxalate: Calcium & 3.02 & 3.14 & 0.40 & 0.95 & 0.28 \\
\hline Oxalate: Magnesium & 0.14 & 0.37 & 0.17 & 0.34 & 0.05 \\
\hline Oxalate: Potassium & 0.06 & 0.19 & 0.09 & 0.06 & 0.02 \\
\hline Oxalate: Iron & 11.13 & 23.89 & 4.23 & 12.04 & 3.10 \\
\hline Phytate: Calcium & 8.89 & 2.61 & 0.26 & 0.53 & 0.76 \\
\hline Phytate: Magnesium & 0.41 & 0.31 & 0.11 & 0.20 & 0.15 \\
\hline Phytate: Potassium & 0.17 & 0.16 & 0.06 & 0.04 & 0.04 \\
\hline Phytate: Iron & 32.77 & 19.92 & 2.73 & 7.05 & 8.40 \\
\hline
\end{tabular}

324

325

326

327

328

329

330

331

332 


\section{Table 4}

334 Molar ratios of phytate with calcium and magnesium and its correlation with soluble:

335 insoluble oxalate

\begin{tabular}{|c|c|c|c|c|c|c|c|}
\hline $\begin{array}{l}\text { Sr. } \\
\text { No }\end{array}$ & $\begin{array}{l}\text { Test } \\
\text { Samples }\end{array}$ & $\begin{array}{l}\text { Phytate } \\
\text { ratio }\end{array}$ & $\begin{array}{l}\text { Calcium } \\
\text { ratio }\end{array}$ & $\begin{array}{l}\text { Magnesium } \\
\text { ratio }\end{array}$ & $\begin{array}{l}\mathrm{Ca}+\mathrm{Mg} \\
\text { ratio }\end{array}$ & $\begin{array}{l}\text { Phytate: } \\
\text { Ca+Mg }\end{array}$ & $\begin{array}{l}\text { Soluble: Insoluble } \\
\text { ratio }\end{array}$ \\
\hline 1 & Wheat Bran & 6.65 & 0.74 & 16.36 & 17.1 & 0.40 & 0.38 \\
\hline 2 & Oat Bran & 1.5 & 0.57 & 4.87 & 5.44 & 0.28 & 0.99 \\
\hline 3 & Barley Bran & 0.34 & 1.34 & 3.07 & 4.41 & 0.08 & 0.81 \\
\hline 4 & Red Bean & 0.93 & 1.74 & 4.7 & 6.44 & 0.14 & 0.21 \\
\hline 5 & White Bean & 1.01 & 1.34 & 6.84 & 8.18 & 0.12 & 0* \\
\hline
\end{tabular}

336

337

*Soluble oxalate $<0.01 \mathrm{mg} / 100 \mathrm{~g}$, so the ratio is $<0.001$. 